\title{
Internal phoshorus loading potential of a semiarid reservoir: an experimental study
}

Potencial de fertilização interna de fósforo de um reservatório semiárido: um estudo experimental

\section{Hérika Cavalcante $^{1 *}$ (D) Fabiana Araújo ${ }^{2}$ (D) Vanessa Becker ${ }^{2}$ (D) and}

\author{
José Etham de Lucena Barbosa ${ }^{3}$ (C)
}

\begin{abstract}
${ }^{1}$ Programa de Pós-graduação em Ciência e Tecnologia Ambiental, Universidade Estadual da Paraíba - UEPB, Campina Grande, PB, Brasil

${ }^{2}$ Laboratório de Recursos Hídricos e Saneamento Ambiental, Departamento de Engenharia Civil, Centro de Tecnologia. Universidade Federal do Rio Grande do Norte - UFRN, Natal, RN, Brasil ${ }^{3}$ Laboratório de Ecologia Aquática, Departamento de Biologia, Universidade Estadual da Paraíba UEPB, Campina Grande, PB, Brasil

*e-mail: herikacavalcante@hotmail.com
\end{abstract}

Cite as: Cavalcante, H., Araújo, F., Becker, V. and Barbosa, J.E.L. Internal phoshorus loading potential of a semiarid reservoir: an experimental study. Acta Limnologica Brasiliensia, 2021, vol. 33, e6.

Abstract: Aim: To determine the internal P loading potential of semiarid tropical reservoir sediment while verifying the driving factors that affect $P$ release rates. Methods: An experiment was performed with water and sediment from the reservoir Boqueirão de Parelhas in Brazil. The effects of three variables on $\mathrm{P}$ release were studied: air temperature (region average of $28{ }^{\circ} \mathrm{C}$ and $32{ }^{\circ} \mathrm{C}$, simulating an increase of $4{ }^{\circ} \mathrm{C}$ ), $\mathrm{pH}$ (region average of $\mathrm{pH} 8$, more acidic $\mathrm{pH} 6$ and more alkaline $\mathrm{pH} 10$ ) and oxygen (presence and absence). In addition, $\mathrm{P}$ fractionation analysis was performed on the $\mathrm{P}$ forms in the sediment. Results: It was found that the minimum P release was in an oxic treatment at $\mathrm{pH} 6$ and temperature $28^{\circ} \mathrm{C}\left(0.22 \mathrm{mg} \mathrm{m}^{-2} \mathrm{~d}^{-1} \pm 0.13\right)$ and the maximum P release in an anoxic treatment at $\mathrm{pH} 10$ and temperature $32^{\circ} \mathrm{C}\left(2.1 \mathrm{mg} \mathrm{m}^{-2} \mathrm{~d}^{-1} \pm 0.15\right)$. The total $\mathrm{P}$ in the sediment was $597 \mathrm{mg} \mathrm{kg}^{-1}$, and the major $\mathrm{P}$ form in the sediment was $\mathrm{NaOH}-\mathrm{rP}$, the $\mathrm{P}$ bound to aluminum, corresponding to $42 \%$ of the total P. Conclusion: These results allow us to confirm that the sediment of the Boqueirão reservoir is susceptible to the release of $\mathrm{P}$ bound to aluminum due to the prevalence of this form in its sediments concomitant with the high temperatures and alkaline $\mathrm{pH}$ of the water. This scenario can be aggravated by climate change.

Keywords: eutrophication; phosphorus fractionation; internal loading; temperature increase.

Resumo: Objetivo: Determinar o potencial de fertilização interna de $\mathrm{P}$ do sedimento de reservatório tropical semiárido, ao mesmo tempo em que verificar os fatores que afetam as taxas de liberação de $P$. Métodos: Foi realizado um experimento com água e sedimento do reservatório Boqueirão de Parelhas, Brasil. Foram estudados os efeitos de três variáveis na liberação de $\mathrm{P}$ : temperatura do ar (região média de $28^{\circ} \mathrm{C}$ e $32^{\circ} \mathrm{C}$, simulando aumento de $4^{\circ} \mathrm{C}$ ), $\mathrm{pH}$ (região média de $\mathrm{pH} 8, \mathrm{pH}$ mais ácido 6 e pH mais alcalino 10) e oxigênio (presença e ausência). Além disso, a análise de fracionamento de $\mathrm{P}$ foi realizada nas formas de $\mathrm{P}$ no sedimento. Resultados: Verificou-se que a liberação mínima de $\mathrm{P}$ foi em tratamento óxico em pH 6 e temperatura $28^{\circ} \mathrm{C}(0,22 \mathrm{mg} \mathrm{m}-2 \mathrm{~d}-1 \pm 0,13)$ e a liberação máxima de $\mathrm{P}$ em tratamento anóxico em $\mathrm{pH} 10$ e temperatura $32{ }^{\circ} \mathrm{C}(2,1 \mathrm{mg} \mathrm{m}-2 \mathrm{~d}-1 \pm 0,15)$. O P total no sedimento foi $597 \mathrm{mg} \mathrm{kg}-1$, e a principal forma de $\mathrm{P}$ no sedimento foi o $\mathrm{NaOH}-\mathrm{rP}$, o $\mathrm{P}$ ligado ao 
alumínio, correspondendo a $42 \%$ do $\mathrm{P}$ total. Conclusão: Esses resultados nos permitem confirmar que o sedimento da represa do Boqueirão é suscetível à liberaçáo de P ligado ao alumínio devido ao predomínio desta forma em seus sedimentos concomitante às altas temperaturas e $\mathrm{pH}$ alcalino da água. Esse cenário pode ser agravado pelas mudanças climáticas.

Palavras-chave: eutrofização; fracionamento de fósforo; fertilização interna; aumento da temperatura.

\section{Introduction}

Eutrophication is a global problem that causes damage to aquatic ecosystems. This process involves the enrichment of nutrients in water, generally phosphorus (P) and nitrogen $(\mathrm{N})$, resulting in phytoplankton growth, especially of potentially toxic cyanobacteria, and the alteration of the structure and function of these ecosystems (Dodds, 2006). Concentrations of $\mathrm{P}$ can be controlled more easily than nitrogen, so eutrophication generally control has focused on P (Smith \& Schindler, 2009).

Whole-lake experiments have shown that a reduction in P inputs can cause a successful reversal of lake eutrophication (Schindler, 2012). However, in some cases, a delay in recovery has been observed because lake sediments can act as a P source: the $\mathrm{P}$ accumulated in the sediment can return to the water column through a process called internal loading (Søndergaard et al., 2001). The release of P from sediments can contribute significantly to the amount of bioavailable $P$ in lake water, feeding the eutrophication process. In external loading, $\mathrm{P}$ enters the system largely in particulate form, which is not directly used by phytoplankton; however, with internal loading, the $\mathrm{P}$ is predominantly in inorganic dissolved form, which is directly available for algal growth (Nurnberg, 2009; Bormans et al., 2016).

Usually, internal loading can be attributed to the dissolution of $\mathrm{P}$ adsorbed to iron oxides and hydroxides on sediment, which return $\mathrm{P}$ to the water column under anoxic conditions (Mortimer, 1941), or the release of $P$ from organic compounds (Gächter \& Meyer, 1993) and polyphosphates in hypereutrophic sediments (Hupfer \& Lewandowski, 2008). However, the phenomenon of $P$ release from sediment is complex and involves others factors beyond redox potential such as $\mathrm{pH}$ and temperature (Søndergaard et al., 2001, 2003).

The $\mathrm{pH}$ of the water-sediment interface is a factor that can affect sorption-adsorption, precipitationdissolution and oxidation-reduction reactions, exerting control over available iron, aluminum and calcium concentrations and influencing $\mathrm{P}$ release from sediment (Christophoridis \& Fytianos, 2006; Jiang et al., 2008). Increasing $\mathrm{pH}$ may release $\mathrm{P}$ bound to metal complexes due to competition between hydroxyl ions and the phosphate ions bound to these metals (Dong et al., 2011), while decreasing $\mathrm{pH}$ may influence the dissolution of calcium and apatite, causing the release of the $\mathrm{P}$ previously bound to these compounds (Golterman, 2001).

From classic investigations (Jensen \& Andersen, 1992) to the more recent studies (Wang et al., 2015), the importance of temperature in P release has been demonstrated. An increase in temperature accelerates chemical processes, increases the chemical diffusion rate (Søndergaard, 2007) and can stimulate the mineralization of organic matter in sediment, causing inorganic phosphate release (Boström \& Pettersson, 1982). Temperature also has a direct impact on the amount of available oxygen because the solubility of oxygen in water depends on temperature (Wetzel, 2001). The temperature can also lengthen and intensify the stratification periods of lakes, increasing anoxia conditions, thus stimulating the diffusion of $\mathrm{P}$ from sediments with redox sensitive P dynamics (Mosley, 2015). Because of this, regions with high temperatures, such as in semiarid regions, are more susceptible to internal P loading.

$\mathrm{P}$ can be present in sediment in several forms or fractions as it has an affinity for various organic and inorganic compounds. The analysis of $\mathrm{P}$ forms in sediment occurs through a sequential procedure known as fractionation that uses various extraction solutions. In decreasing order of potential bioavailability or mobility, $\mathrm{P}$ fractions can be characterized as follows: $\mathrm{P}$ still present in interstitial water or weakly bound on the surface of sediment, $\mathrm{P}$ bound to iron and aluminum oxides and hydroxides and $\mathrm{P}$ bound to calcium, apatite and carbonates, which are considered more refractory (Søndergaard et al., 2003). Knowing the P fractions in sediment in detail rather than simply the total $\mathrm{P}$ (TP) is essential as TP cannot correctly predict the potential of sediment as a source of internal loading (Rydin, 2000).

Brazilian semiarid regions have been characterized by high temperatures and annual low precipitation levels that occur in a concentrated manner (Silva et al., 2010; Barbosa et al., 2012). Those 
characteristics can result in an intensification of the eutrophication process and lead to a consequent increase in the occurrence of cyanobacterial blooms, rendering waters unfit for consumption and irrigation (Huszar et al., 2000; Medeiros et al., 2015; Brasil et al., 2016). In recent years, extreme events such as prolonged droughts have occurred with greater severity, and the period between them appears to have become shorter in some regions (Mishra \& Singh, 2010; Moss, 2014). Semiarid regions are highly vulnerable to droughts, and climate change scenarios indicate that these regions will be affected by rainfall deficits and increased aridity in the second half of $21^{\text {st }}$ century (IPCC, 2014; Marengo et al., 2018), causing fluctuations in water levels and nutrient concentrations that can further intensify eutrophication symptoms (Moss, 2014).

The scenario in Brazilian semiarid regions makes it important to take measures to control eutrophication, which require good knowledge about the dynamics of phosphorus in the lake. However, the region still has scarcity of data, mainly on $\mathrm{P}$ content in the sediment and how the release of $\mathrm{P}$ behaves in the face of the variation of the main factors that influence it. In light of prior reports and in order to better understand how this system functions, the aim of this study was to determine the internal $\mathrm{P}$ loading potential of a semiarid tropical eutrophic reservoir while verifying the driving factors that affect $P$ release rates.

\section{Methods}

\subsection{Study site}

This study was performed with water and sediment from the Boqueirão de Parelhas reservoir located in the Piranhas-Açu watershed of the Northeast Region of Brazil (Figure 1). According to the reservoir's datasheet, available on the website of the Secretariat of environment and water resources of Rio Grande do Norte State (SEMARH), Boqueirão reservoir was built in 1988 , has a maximum capacity of 84,8 million $\mathrm{m}^{3}, 29 \mathrm{~m}$ maximum depth and has multiple uses, with priority given to human water supply.

The climate of the region is described by Köppen's climate classification as BSh: dry, semiarid and low latitude and altitude (Alvares et al., 2014); with average temperature between 23 and $28^{\circ} \mathrm{C}$ and annual precipitation between 400 and $800 \mathrm{~mm}$ (Silva et al., 2010; Barbosa et al., 2012). The predominant soil in the watershed is classified as Litolic Neosoil, which is characterized by being
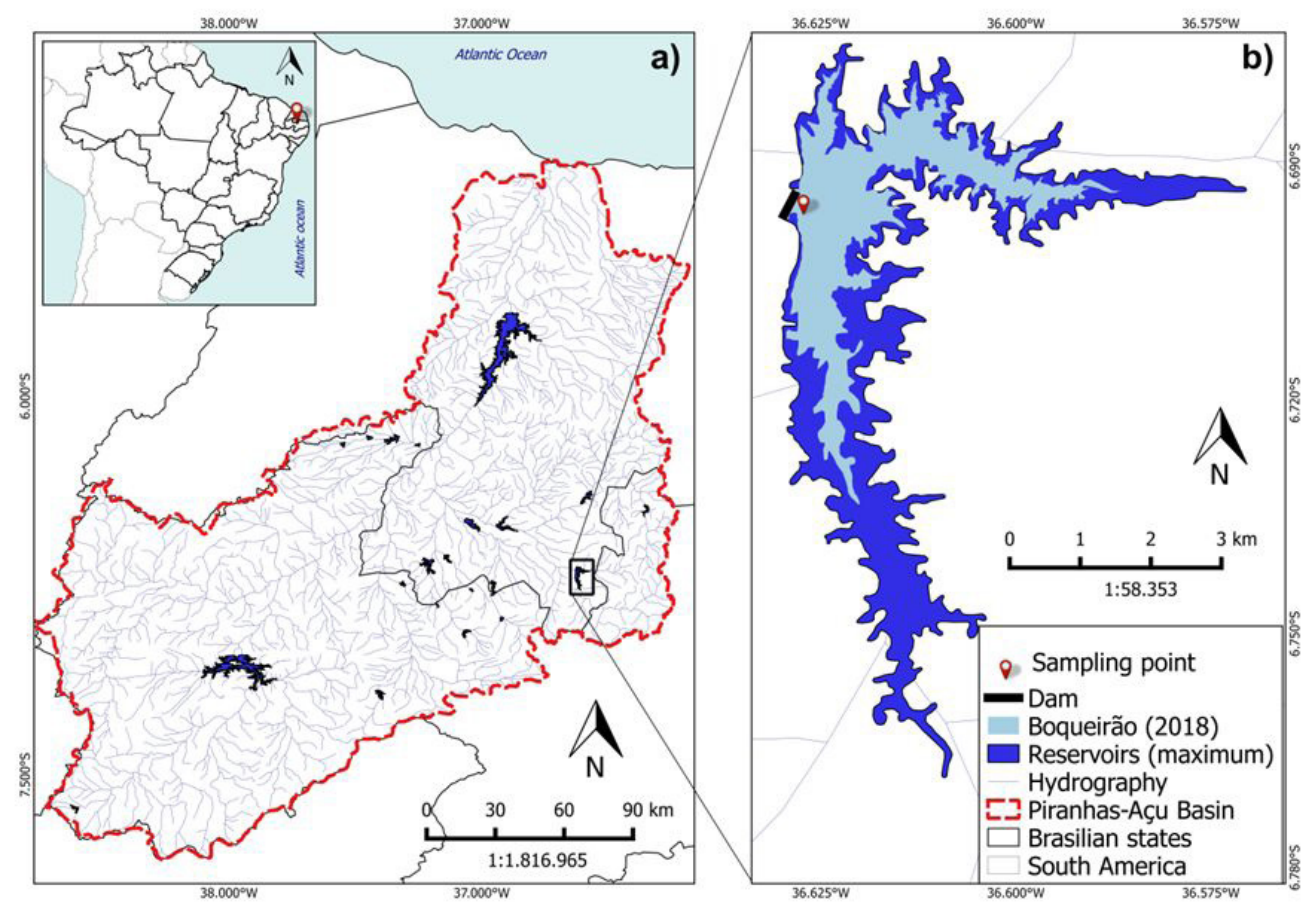

Figure 1. Study area: a) Piranhas-Açu watershed and b) Boqueirão de Parelhas reservoir, with the sampling station (red and white point) near the dam (black stroke). The surface area in 2018 is illustrated by the light blue area in the figure $b$ and was determined through a Google Earth image from October 2018. The dark blue area represents the maximum surface area that is reached when the reservoirs reaches its maximum volume. 
a young soil, poorly devolved genetically, small thickness and elevated sandy activity (Embrapa, 2018).

\subsection{Samplings}

Water and sediment samples were collected at a point near the reservoir dam and the water catchment tower for the human supply (Figure 1). Sediment cores of $10 \mathrm{~cm}$ were sampled in March 2018 using a manual Kajak core sampler $(50 \mathrm{~cm}$ long, $7 \mathrm{~cm}$ in diameter). This core depth $(10 \mathrm{~cm})$ was chosen because it is used in several other studies (Reitzel et al., 2003, 2005; Jensen et al., 2015). Water samples were collected, through a Van Dorn bottle, monthly, between November 2017 and March 2018 at the surface and at the bottom, for the physical and chemical water characterization. For the Sediment phosphorus release experiment only bottom water was utilized, collected in March 2018. All samples (sediment and water) were closed, left in the dark and transported to the laboratory at room temperature.

\subsection{Water sample analysis}

The following variables were measured in situ: water depth, with a depth gauge; water temperature and dissolved oxygen (every meter of the water column), with oximeter (Instrutherm MO-900). The volume data stored in the reservoir were obtained from the SEMARH-RN website. Upon arriving at the laboratory, the following variables were measured: $\mathrm{pH}$, with $\mathrm{pH}$ meter (BEL W3B); soluble reactive $\mathrm{P}$ (SRP), by ascorbic acid method after filtration with cellulose membrane $(\varnothing=0.45 \nabla \mathrm{m})$, followed by spectrophotometry (Murphy \& Riley, 1962); total P (TP), by oxidation with potassium persulfate (Valderrama, 1981) followed by ascorbic acid method and spectrophotometry (Murphy \& Riley, 1962); chlorophyll-a (Chl-a), extracted after glass fiber membrane filtration $(\varnothing=1.2 \otimes \mathrm{m})$ with 95\% ethanol (Jespersen \& Christoffersen, 1988).

\subsection{Sediment sample analysis}

The $\mathrm{P}$ forms in the sediment were analyzed according the methodology described by Cavalcante et al. (2018). This method uses a sequential chemical extraction process called fractionation and determines seven P forms: (1) Water-P or porewater-P, extracted with anoxic water (by introduced $\mathrm{N}_{2}$ ) and representing a more labile fraction present in the interstitial water in sediment; (2) BD-P, extracted with a solution of bicarbonate and sodium dithionite and representing $\mathrm{P}$ forms sensitive to low redox potential, such as $\mathrm{P}$ adsorbed on the surface of iron $(\mathrm{Fe})$ and manganese $(\mathrm{Mn})$; (3) $\mathrm{NaOH}-\mathrm{rP}$, extracted with a sodium hydroxide solution, representing the $\mathrm{P}$ exchangeable with $\mathrm{OH}^{-}$, mainly aluminum, but also inside iron oxides. Also extracted in this step and detected after digestion, is (4) $\mathrm{NaOH}-\mathrm{nrP}$, organic-P including bacteria-incorporated-P; still in this step is formed after acidification with sulfuric acid, a precipitate interpreted as (5) Humic-P, P bound to humic substances; (6) HCl-P, extracted with a hydrochloric acid solution, $\mathrm{P}$ forms sensitive to low $\mathrm{pH}$, assumed to consist mainly of calcium and apatite; and (7) Resiual-P, consisting mainly of refractory organic $\mathrm{P}$ and the inert inorganic $\mathrm{P}$, considered to be non-mobile.

\subsection{Sediment phosphorus release experiment}

To evaluate the $P$ release rate from the sediment to the water column, $150 \mathrm{~g}$ of the $10 \mathrm{~cm}$ of the sediment and $900 \mathrm{ml}$ of bottom water were introduced into sealed glass vessels for 21 days. The water had been previously filtered $(\varnothing=0.6 \mu \mathrm{m})$ to remove planktonic organisms, and to avoid oxygen generation by photosynthetic organisms, the recipients were kept in the dark.

The effects of three variables on $\mathrm{P}$ release were studied: i) air temperature (controlled by incubators), ii) $\mathrm{pH}$ (controlled by $\mathrm{HCl}$ or $\mathrm{NaOH}$ titration) and iii) $\mathrm{DO}$ (controlled by $\mathrm{N}$ gas injection or aeration through bombs). The temperatures used in the incubators were $28^{\circ} \mathrm{C}$, chosen as an annual average reservoir temperature based on data from the Empresa Brasileira de Pesquisa Agropecuária (Silva et al., 2010), and $32{ }^{\circ} \mathrm{C}$, simulating a $4{ }^{\circ} \mathrm{C}$ increase over the average value based on a pessimistic scenario from the IPCC (IPCC, 2014) . The $\mathrm{pH}$ values were $\mathrm{pH} 8$ used as an average for the water and based on the characterization of a semiarid region (Barbosa et al., 2012), pH 6 as more acidic than average and $\mathrm{pH} 10$ as more alkaline than average. The DO conditions were anoxic conditions (ANOX), with DO less than $1 \mathrm{mg} \mathrm{L}^{-1}$ and the samples kept in a closed beaker covered with plastic film, and oxic conditions (OXI), with DO higher than $5 \mathrm{mg} \mathrm{L}^{-1}$. In summary, the experiment had a factorial design of $2 \times 3 \times 2$ (temperature $\mathrm{x} \mathrm{pH} \times$ oxygen condition), in which 12 treatments were done in triplicate for a total of 36 experimental units.

Aliquots $(20 \mathrm{ml})$ for the SRP analysis were taken on days: 0 (initial conditions, before water insertion), 1 (24 hours after water insertion), 7 , 14 and 21. On the days of aliquot collection, the 
variables of water temperature, $\mathrm{pH}$ and $\mathrm{DO}$ were measured only for verification and to ensure the experimental conditions. The removed water was replaced with filtered $(\varnothing=0.6 \mu \mathrm{m})$ reservoir water (kept in incubators together with the microcosms). Based on the TP concentrations in the water per the day of analysis, it was possible to calculate the P flux from the sediment to the water, that is, the release rate of the P (Equation 1) (He et al., 2017).

$P_{F l u x}=\left(\frac{\left(C_{t}-C_{i}\right)^{*} V}{A^{*} t}\right) / 1000$

$P_{f l u x}=\mathrm{P}$ flux from the sediment to the water $\left(\mathrm{mg} \mathrm{m}^{-2} \mathrm{~d}^{-1}\right)$

$C_{t}=\mathrm{P}$ concentration in the water at time " $\mathrm{t}$ " $\left(\mu \mathrm{g} \mathrm{\textrm {L } ^ { - 1 } )}\right.$

$C_{i}=$ Initial $\mathrm{P}$ concentration in the water $\left(\mu \mathrm{g} \mathrm{L}^{-1}\right)$

$V=$ Water volume $=0.9 \mathrm{~L}$

$A=$ Sediment surface area in the beaker or beaker base area $=0.008 \mathrm{~m}^{2}$

$t=$ Experiment duration time $=21$ days

\subsection{Statistical analyses}

To verify the significant effects of temperature, $\mathrm{pH}$ and oxygen level and their interaction with the $P$ release rate, a three-way ANOVA was performed. This was followed by Tukey's multiple comparison tests. Normality and homoscedasticity were assessed using Kolmogorov-Smirnov and Levene's tests, respectively. Statistical analyses were performed using $\mathrm{R}$ Software for Windows, considering a significance level of $5 \%$.

\section{Results}

During the sampling period for this study, water volume was around 19 million $\mathrm{m}^{3}$, which corresponds to $23 \%$ of the maximum capacity (Table 1). This reduced the reservoir's surface area (Figure 1) and the depth of the sampling point, which was approximately $10 \mathrm{~m}$ (Table 1). In addition, the water from the reservoir showed high temperature, low oxygen (without anoxic conditions), alkaline $\mathrm{pH}$, high total phosphorus, high reactive phosphorus and high chlorophyll-a (Table 1).

The results of the experiment showed an increase in $\mathrm{P}$ concentration in the water of each sample treatment throughout the experiment period (Figure 2). The largest increase was observed between days 7 and 14. After that, there was a decrease or stabilization in the amount of $\mathrm{P}$ in the water for some of the treatments, and so day 21 was chosen as the last day of aliquot collection for analysis. The driving factors affecting $\mathrm{P}$ release rates were high $\mathrm{pH}$ and temperature, as the highest $\mathrm{P}$ release rates were in the treatments with $\mathrm{pH} 10$ mainly at $32{ }^{\circ} \mathrm{C}$ (Figure $2 \mathrm{c}$ and $\mathrm{d}$ ).

All treatments showed positive $\mathrm{P}$ release rates during the 21 days of the experiment (Figure 3). $\mathrm{P}_{\text {flux }}$ increased proportionally to an increase in $\mathrm{pH}\left(\mathrm{F}_{(2,24)}=77 ; \mathrm{p}<0.0001\right)$ and temperature $\left(\mathrm{F}_{(1,24)}=38.6 ; \mathrm{p}<0.0001\right)$ and under anoxic conditions $\left(\mathrm{F}_{(1,24)}=21 ; \mathrm{p}=0.0001\right)$, with significant interaction between $\mathrm{pH}$ x temperature $\left(\mathrm{F}_{(2,24)}=8 ; \mathrm{p}=0.0019\right)$, $\mathrm{pH}$ x oxygen $\left(\mathrm{F}_{(2,24)}=4 ; \mathrm{p}=0.033\right)$ and temperature $\mathrm{x}$ oxygen $\left(\mathrm{F}_{(1,24)}=4.6 ; \mathrm{p}=0.042\right)$. The lowest release rate was in the $\mathrm{pH} 6$ OXI $28^{\circ} \mathrm{C}$ treatment $\left(0.22 \mathrm{mg} \mathrm{m}^{-2} \mathrm{~d}^{-1} \pm 0.13\right)$ and the highest in the $\mathrm{pH}$ 10 ANOX $32^{\circ} \mathrm{C}$ treatment $\left(2.1 \mathrm{mg} \mathrm{m}^{-2} \mathrm{~d}^{-1} \pm 0.15\right)$.

The results for the $\mathrm{P}$ fractionation before the experiment $(\mathrm{PBE})$ showed that there was a pool of $594 \mathrm{mg}$ of $\mathrm{P}$ per kilogram of sediment in the Boqueirão reservoir (Figure 4). The decreasing order of P forms was: NaOH-P $\left(250 \mathrm{mg} \mathrm{kg}^{-1}\right.$, $42 \%)>$ BD-P $\left(120 \mathrm{mg} \mathrm{kg}^{-1}, 20 \%\right)>\mathrm{NaOH}-\mathrm{nrP}$ $\left(83.3 \mathrm{mg} \mathrm{kg}^{-1}, 14 \%\right)>\mathrm{HCl}-\mathrm{P}\left(61.8 \mathrm{mg} \mathrm{kg}^{-1}, 10 \%\right)$ $>$ residual-P $\left(40 \mathrm{mg} \mathrm{kg}^{-1}, 7 \%\right)>$ humic-P $(22.9 \mathrm{mg}$ $\left.\mathrm{kg}^{-1}, 4 \%\right)>$ water-P $\left(15.8 \mathrm{mg} \mathrm{kg}^{-1}, 3 \%\right)$. NaOH-P was the major fraction in the sediment, with an average value greater than double the second most prevalent form. P values after the experiment were slightly reduced in some treatments but were not significantly different from the results prior to the experiment either in mass or percentage (Figure 4).

Table 1. Mean, minimum (Min), maximum (Max) and standard deviation (SD) of physicochemical variables and chlorophyll-a in Boqueirão reservoir water analyzed monthly from November 2017 to March 2018.

\begin{tabular}{lcccc}
\hline \multicolumn{1}{c}{ Parameter } & Mean & Min & Max & Sd \\
\hline Stored volume $(\%)$ & $23 \%$ & $11 \%$ & $42 \%$ & $15 \%$ \\
Water depth $(\mathrm{m})$ & 10 & 8 & 12 & 2 \\
Water Temperature $\left({ }^{\circ} \mathrm{C}\right)$ & 29 & 28 & 30 & 1 \\
Dissolved Oxygen $\left(\mathrm{mg} \mathrm{L}^{-1}\right)$ & 4.8 & 1.6 & 8 & 3 \\
$\mathrm{pH}$ & 8.2 & 7.3 & 9.2 & 0.9 \\
Total Phosphorus $\left(\mu \mathrm{g} \mathrm{L}^{-1}\right)$ & 74.6 & 52 & 153 & 65 \\
Soluble Reactive Phosphorus $\left(\mu \mathrm{g} \mathrm{L}^{-1}\right)$ & 56 & 14 & 97 & 32 \\
Chlorophyll-a $\left(\mu \mathrm{g} \mathrm{L}^{-1}\right)$ & 77 & 22 & 197 & 81 \\
\hline
\end{tabular}



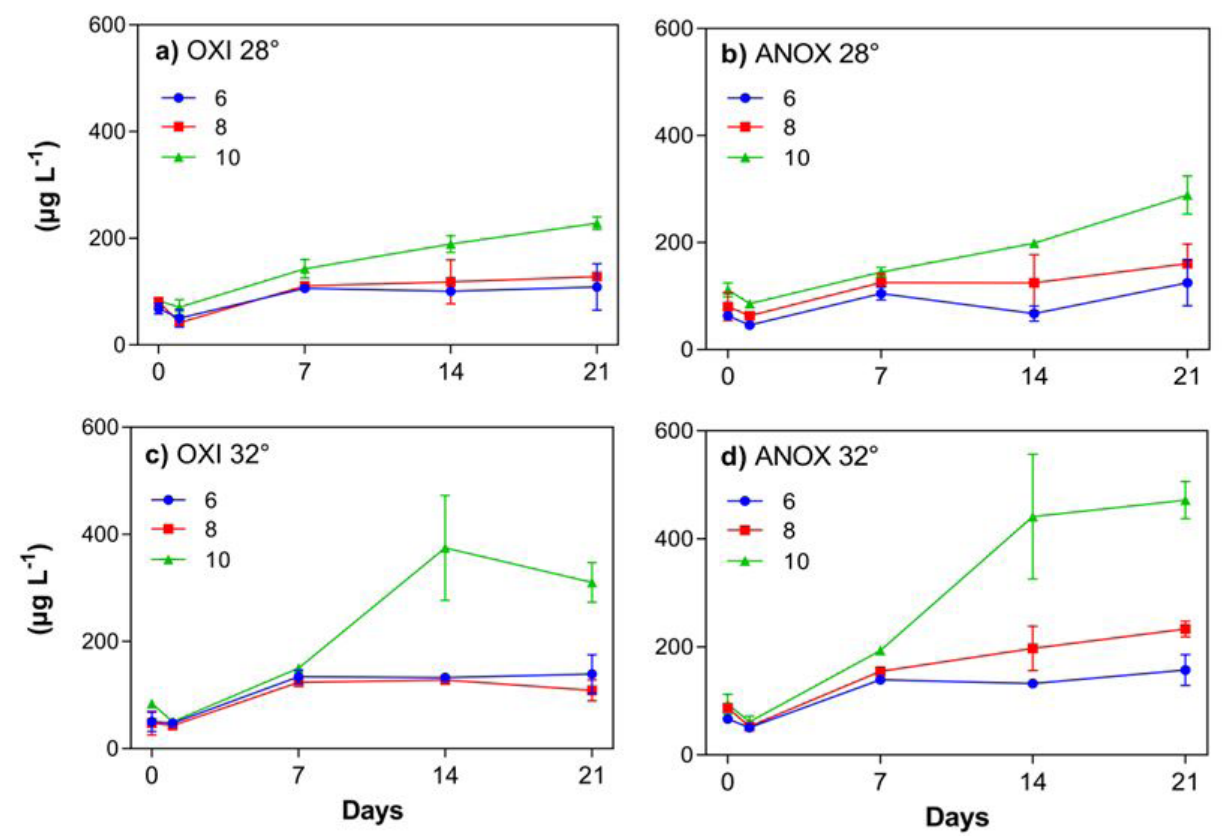

Figure 2. Variation in the soluble reactive phosphorus (SRP) in the overlying water of the Boqueirão reservoir during the 21 days of the experiment. a) At $28^{\circ} \mathrm{C}$, under oxic conditions and $\mathrm{pH}$ values 6,8 and 10 ; b) At $28^{\circ} \mathrm{C}$, under anoxic conditions and $\mathrm{pH}$ values 6,8 and $10 ; \mathrm{c}$ ) At $32^{\circ} \mathrm{C}$, under oxic conditions and $\mathrm{pH}$ values 6,8 and 10 ; d) At $32^{\circ} \mathrm{C}$, under anoxic conditions and $\mathrm{pH}$ values 6,8 and 10 . OXI $=$ oxic treatment (dissolved oxygen $>5 \mathrm{mg} \mathrm{L}^{-1}$ ) and ANOX = anoxic treatment (dissolved oxygen $\left.<1 \mathrm{mg} \mathrm{L}^{-1}\right)$.

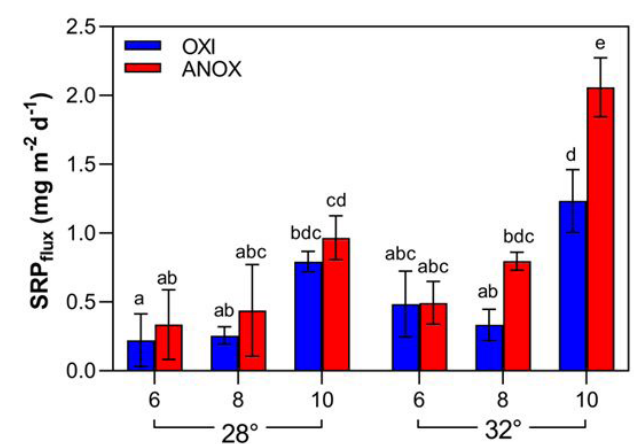

Figure 3. The phosphorus flux/phosphorus release rate $\left(\mathrm{P}_{\text {flux }}, \mathrm{mg} \mathrm{m}^{-2} \mathrm{~d}^{-1}\right)$ from the sediment to the water of the Boqueirão reservoir after the 21 days of the experiment for different variations of $\mathrm{pH}(6,8$ and 10$)$, oxygen (oxic and anoxic conditions) and temperature $\left(28^{\circ} \mathrm{C}\right.$ and $32^{\circ} \mathrm{C}$ ). Means followed by the same letter do not differ from each other by the Tukey's test for $\mathrm{p} \leq 0.05$. OXI $=$ oxic treatment (dissolved oxygen $>5 \mathrm{mg} \mathrm{L}^{-1}$ ), ANOX = anoxic treatment $\left(\right.$ dissolved oxygen $\left.<1 \mathrm{mg} \mathrm{L}^{-1}\right)$.

\section{Discussion}

During the period studied, Boqueirão presented a low stored volume, around $20 \%$ of the water maximum capacity, following the trend of several other reservoirs in semiarid regions. This reduction occurred due a prolonged drought event that region experienced during 2012 to 2016 (Marengo et al., 2018). The water quality of these environments also
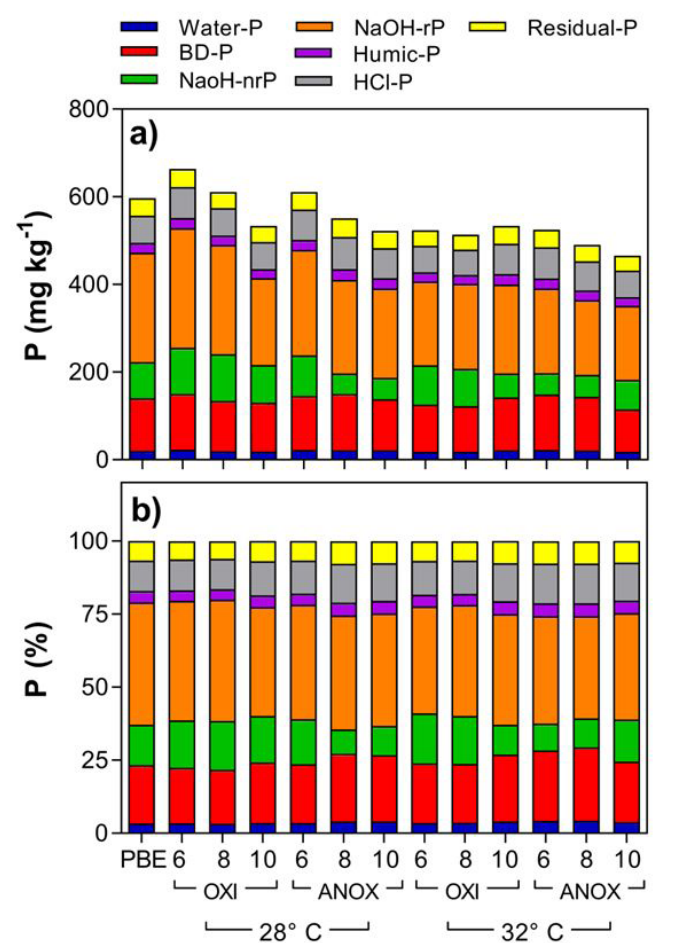

Figure 4. Phosphorus ( $\mathrm{P})$ forms a) in mass $\left(\mathrm{mg} \mathrm{kg}^{-1}\right)$ and $\mathrm{b}$ ) in percentage (\%) present in upper $10 \mathrm{~cm}$ of the Boqueirão reservoir sediment. ${ }^{*} \mathrm{PBE}=\mathrm{P}$ before the experiment. $\mathrm{BD}=$ bicarbonate dithionite. $\mathrm{OXI}=$ oxic treatment $\left(\mathrm{DO}>5 \mathrm{mg} \mathrm{L}^{-1}\right), \mathrm{ANOX}=$ anoxic treatment $\left(\mathrm{DO}<1 \mathrm{mg} \mathrm{L}^{-1}\right)$. 
decreased considerably in this period (Figueiredo \& Becker, 2018; Rocha Junior et al., 2018; Leite \& Becker, 2019). Some years earlier, Boqueirão reservoir was considered oligotrophic, and since 2014 the eutrophication process has begun to intensify (Mendonça-Júnior et al., 2018). Actually, according to the total phosphorus (TP) and Chloropill-a analyzed in this study, the reservoir is eutrophic by Thornton \& Rast (1993) classification. In addition, the experimental results showed that the sediment from the Boqueirão has a potential for P release, further worsening the eutrophication of the environment.

The values of $\mathrm{P}$ release rates found in this study $\left(0.22-2.1 \mathrm{mg} \mathrm{m}^{-2} \mathrm{~d}^{-1}\right)$ were lower than the P flux found in recent studies: in Jacarepaguá Lagoon, Brazil (2.5-9.2 $\mathrm{mg} \mathrm{m}^{-2} \mathrm{~d}^{-1}$ ) (Marinho et al., 2020); in two semiarid reservoirs, Brazil ( 4 and $10 \mathrm{mg} \mathrm{m}^{-2} \mathrm{~d}^{-1}$ ) (Moura et al., 2020); and lake Diefenbaker, Canada $\left(15-20 \mathrm{mg} \mathrm{m}^{-2} \mathrm{~d}^{-1}\right)$ (Doig et al., 2017). However, the rates of this study were similar to the values found in hypereutrophic lakes in China, as Yangcheng (1.1 to $1.5 \mathrm{mg} \mathrm{m}^{-2} \mathrm{~d}^{-1}$ ) (Yang et al., 2020b) and Lake Chaohu (0.03 to $3.34 \mathrm{mg} \mathrm{m}^{-2} \mathrm{~d}^{-1}$ ) (Yang et al., 2020a); and higher than other environments also in China: wetlands sediments (0.002 to $0.014 \mathrm{mg}$ $\left.\mathrm{m}^{-2} \mathrm{~d}^{-1}\right)$ (He et al., 2017) and Yangtze river (0.105 to $0.143 \mathrm{mg} \mathrm{m}^{-2} \mathrm{~d}^{-1}$ ) (Zhu et al., 2012). This variation in values of sediment release rates demonstrates how complex the internal loading process is, which can be the result of many variables: pollution level of environment (external loading), soil composition, water physicochemical parameters, sedimentation rates and other factors.

The main aim of this study was to verify the driving factors of the $\mathrm{P}$ release rates. Of the three variables analyzed (OD, $\mathrm{pH}$ and temperature), $\mathrm{pH}$ had the greatest influence on $\mathrm{P}$ release. All $\mathrm{pH}$ values (6, 8 and 10) tested in this study showed a positive $\mathrm{P}$ release, but it was lower in $\mathrm{pH} 6$ and higher in $\mathrm{pH}$ 10. Previous studies have demonstrated that $P$ release occurs under both acidic and alkaline conditions, but the release is greater in alkaline (Jin et al., 2006; Li et al., 2013; Yang et al., 2020a), which we also found in this study.

The surface charge properties of soil particles are altered by $\mathrm{pH}$, changing their aggregation and cohesion behavior (Illés \& Tombácz, 2006). Under acidic conditions, there is no aggregation or sedimentation as the particles are negatively charged. This scenario is conducive to the release of the $\mathrm{P}$ linked to calcium and apatite as acidic $\mathrm{pH}$ increases the dissolution of these compounds (Golterman,
2001). However, this $\mathrm{P}$ form is a relatively stable fraction and has been attributed to the permanent burial of P in sediments (Gonsiorczyk et al., 1998). Under neutral conditions, an electric equilibrium occurs, decreasing release. However, $\mathrm{pH}$ interferes more greatly in the release of metal-bound $\mathrm{P}$, such as on iron and aluminum, under mainly alkaline conditions (Kim et al., 2003). Under alkaline conditions, the capacity for $\mathrm{P}$ to bind to iron and aluminum compounds is decreased due to ion exchange reactions in which hydroxide $\left(\mathrm{OH}^{-}\right)$ions replace orthophosphate ions because $\mathrm{OH}^{-}$has a stronger coordination competition capacity than phosphate, which is then released to the water column (Wang et al., 2015). That is most likely what happened in this study due to the predominance (42\%) of the $\mathrm{NaOH}-\mathrm{rP}$ form in the sediment. $\mathrm{NaOH}-\mathrm{rP}$ represents the $\mathrm{P}$ bound to aluminum oxide surfaces and inside iron oxides, and under high $\mathrm{pH}$ conditions, this $\mathrm{P}$ can be exchanged with $\mathrm{OH}^{-}$and released to the water column (Kozerski \& Kleeberg, 1998).

Increasing the temperature also significantly increased the P-release rate. Temperature can interfere with internal loading in several ways: accelerate chemical processes, increase diffusion rates, stimulate mineralization of organic matter and solubilize oxygen in water (Jensen \& Andersen, 1992; Gächter \& Meyer, 1993; Coffman \& Kildsig, 1996; Cornelissen et al., 1997). In this study, the greatest $\mathrm{P}$ release was at $32{ }^{\circ} \mathrm{C}$, which may be due to the increased intensity in the coordination competition between the $\mathrm{OH}^{-}$and phosphate of the $\mathrm{NaOH}-\mathrm{rP}$ form, which was also found by Wang et al. (2015). In addition, the temperature presented a significant interaction with $\mathrm{pH}$, proving that there was a synergistic relationship between these factors: increasing temperature and $\mathrm{pH}$ promoted the release of $\mathrm{P}$ in this experiment, most likely from the $\mathrm{NaOH}-\mathrm{rP}$ fraction because this fraction is the most affected by alkaline $\mathrm{pH}$ and high temperatures.

The DO factor did not interfere as much as the other factors: P release was only slightly increased when conditions were anoxic. Oxygen level is an important factor in the $\mathrm{P}$ release process, affecting mainly the $\mathrm{P}$ forms considered more mobile: water-P, BD-P and NaOH-nrP (Rydin, 2000). The water-P is the loosely bound form on the surface of sediment or in interstitial water and considered immediately available (Hupfer \& Lewandowski, 2008). BD-P is the P bound to reducible forms of iron and manganese. $\mathrm{NaOH}-n r P$ corresponds to 
organic forms of $\mathrm{P}$ such as polyphosphates, which can be released from bacterial cells (Gächter et al., 1988), or phytate (inositol hexaphosphate), which is strongly adsorbed to iron oxides and can be mobilized when exposed to anoxic conditions (De Groot \& Golterman, 1993). However, oxygen level has not shown a fundamental role in the P release from the Boqueirão reservoir sediment, possibly due the low values of the $\mathrm{P}$ forms considered mobile (water $-3 \%, \mathrm{BD}-20 \%$ and $\mathrm{NaOH}-\mathrm{nrP}-14 \%$ ) in comparison to the $\mathrm{NaOH}-\mathrm{rP}$. This fact can demonstrate that the concept of "potentially mobile P" depends on the studied environment.

In restoration projects or studies aimed at reducing the internal loading, some products, such as clays or other material with an affinity for P, can be applied over the sediment, in order to form a layer that prevents the $\mathrm{P}$ release (Mackay et al., 2014). Most of the time, these products are dosed based on the amount of "potentially mobile P", which is the sum of water-P, BD-P, and $\mathrm{NaOH}-\mathrm{nrP}$, since these fractions are considered the $\mathrm{P}$ that can be released during anoxic periods and by degradation of organic matter (Reitzel et al., 2005; Vicente et al., 2008). The concept of "potentially mobile P" was developed based on studies of the environments with characteristics different to tropical semiarid reservoirs. In a study about dosing aluminum relative to mobile $P$, realized in a Denmark Lake, Reitzel et al. (2005) suggest that the development of the concept of "potentially mobile P" to other sediment types provide important information regarding the source for internal $\mathrm{P}$ loading, and thereby this concept is an important tool in lake management. The results of this study suggest that Boqueirão reservoir sediments are susceptible to release of $\mathrm{NaOH}-\mathrm{rP}$ content due to natural alkaline $\mathrm{pH}$ (mean 8) and elevated water temperature (mean $29{ }^{\circ} \mathrm{C}$ ). In practical terms, this means that the amount of $\mathrm{NaOH}-\mathrm{rP}$ should be considered when calculating the dosage of products for application in environments with similar characteristics, especially in the tropical semiarid, a region with limited data about internal loading and where the "potentially mobile P" concept may still needs to be developed.

Even with an increase in the concentration of $\mathrm{P}$ in the water column of treatments, there were no significant differences between the P-form values in the sediment before and after the experiment as estimated by fractionation. This is most likely because the amount of $\mathrm{P}$ released in 21 days was much less than the amount in the sediment. However, the release of $\mathrm{P}$ from sediment can sustain the concentrations of nutrients in overlying water thereby inducing the blooming of algae (Yang et al., 2020a). In this study, the results showed that for the water, there was already been a significant increase in the P during the experiment days. Under natural conditions, this $\mathrm{P}$ can be quickly incorporated by primary producers in just 21 days, mainly in shallow water bodies. This feeds the eutrophication process and worsens over years of internal loading. It is well established that sediment $\mathrm{P}$ is an important internal $\mathrm{P}$ source until the pool of accumulated and releasable P decreases or is deeply buried and permanently in sediment (Søndergaard et al., 2013). Moreover, internal P loading may be very persistent and even after meaningful reductions in external loading, it can still last for at least 10-15 years (Jeppesen et al., 2005).

The amount of $\mathrm{P}$ in the Boqueirão sediment can be considered high, despite being lower than the values found for other reservoirs in the same basin (Cavalcante et al., 2018), which can be justified by the age of reservoir. An experimental study with sediment from three Brazilian Semiarid reservoirs was able to develop a model to describe the effect of the age of the reservoir on the concentration of $\mathrm{P}$ bound to iron and aluminium (Moura et al., 2020). According to the linear relationship found by Moura et al. (2020), a reservoir 30 years old reservoir (i.e. Boqueirão age) should have an amount of $\mathrm{P}$ bound to iron and aluminium of approximately $510 \mathrm{mg} \mathrm{kg}^{-1}$, which matches the amount found in this work, a mean of $453 \mathrm{mg} \mathrm{kg}^{-1}$. The reservoirs studied by Cavalcante et al. (2018), located in the same basin that Boqueirão, which is between 60 and 90 years, therefore, they presented higher $\mathrm{P}$ values. It is worth mentioning that, although the Moura et al. (2020) model seems to adjust to the quantification of $\mathrm{P}-\mathrm{Fe} / \mathrm{Al}$ according to the age of the reservoirs in the semiarid region, the amount of $\mathrm{P}$ in the sediment may still depend on sedimentation rates and local soil composition (Gonsiorczyk et al., 1998; Kaiserli et al., 2002).

The region around the contribution basin of the Boqueirão reservoir, more specifically the municipalities of Parelhas (Rio Grande do Norte State) and Pedra Lavrada (Paraíba State), have a consolidated ceramic industry. The soils in the region, from which the raw materials used in the ceramic industries are extracted, are commonly rich in such as kaolinite, mineral with high alumina $\left(\mathrm{Al}_{2} \mathrm{O}_{3}\right)$ content (Dutra et al., 2008; Formiga et al., 2013; Silva et al., 2013; Ramos et al., 2019). Studies show that $\mathrm{P}$ adsorption can happen intensely in soils 
with an abundance of kaolinite (Novais et al., 2007; Vilar et al., 2010). Therefore, the high P bound to aluminium $(\mathrm{NaOH}-\mathrm{rP})$ value in the Boqueirão sediment may be associated with high amounts of kaolinite from the soils in the region.

In summary, this study provides information on the internal loading potential of a tropical semiarid reservoir, a region that has a scarcity of studies on this topic. In addition, despite having $\mathrm{P}$ inputs from point sources, most $\mathrm{P}$ inputs in reservoirs in the studied region are diffuse, coming from sources such as cropland and pastureland cover and entering the water body by allochthonous runoff during sporadic rainy events (Nobre et al., 2020). However, in the periods of drought experienced by the region, diffuse inputs are practically nonexistent, so internal loading ends up having an even greater importance. This scenario can be further aggravated by climate change. The IPCC has indicated four scenarios for global temperature increase, including among them one of approximately $4^{\circ} \mathrm{C}$, which was the scenario simulated in the experiment of this study. If these forecasts are confirmed, there may be a major impact on the internal $P$ loading of aquatic environments, increasing autochthonous materials especially in warmer regions such as semiarid (Roland et al., 2012). Thus, this work provides basic support for attempts to reduce or control $P$ release from sediments in environments with characteristics similar to the studied environment. It is worth mentioning that however similar the characteristics may be, each lake is unique, and the mitigation should be a tailor made solution (Björk, 1972; Lürling \& Van Oosterhout, 2013), and so it is necessary to understand each specific aquatic environment.

\section{Acknowledgements}

The authors are thankful to Brazilian National Council for Scientific and Technological Development (CNPq) for financial support through the Universal Grant (Processes 407783/2016-4 and 431678/2018-8). We are thankful for the field and technical support team: ELISA (Estudos Limnológicos no semiárido) from Federal University of Rio Grande do Norte; and LEAq (Laboratório de Ecologia Aquática-) from Paraíba State University. This research was financed in part by the Coordenação de Aperfeiçoamento de Pessoal de Nível Superior - Brazil (CAPES) - Finance Code 001.

\section{References}

ALVARES, C.A., STAPE, J.L., SENTELHAS, P.C., GONÇALVES, J.L.M. and SPAROVEK, G.
Köppen's climate classification map for Brazil. Meteorologische Zeitschrift, 2014, 22(6), 711-728.

BARBOSA, J.E.L., MEDEIROS E.S.F., BRASIL, J., CORDEIRO, R.S., CRISPIM, M.C.B. and SILVA, G.H.G. Aquatic systems in semi-arid Brazil: limnology and management. Acta Limnologica Brasiliensia, 2012, 24(1), 103-118.

BJÖRK, S. Swedish lake restoration program gets results. Ambio, 1972, 1(5), 153-165.

BORMANS, M., MARŠÁLEK, B. and JANČULA, D. Controlling internal phosphorus loading in lakes by physical methods to reduce cyanobacterial blooms: a review. Aquatic Ecology, 2016, 50(3), 407-422. http:// dx.doi.org/10.1007/s10452-015-9564-x.

BOSTRÖM, B. and PETTERSSON, K. Different patterns of phosphorus release from lake sediments in laboratory experiments. Hydrobiologia, 1982, 92(0), 415-429. http://dx.doi.org/10.1007/PL00020032.

BRASIL, J., ATTAYDE, J.L., VASCONCELOS, F.R., DANTAS, D.D.F. and HUSZAR, V.L.M. Droughtinduced water-level reduction favors cyanobacteria blooms in tropical shallow lakes. Hydrobiologia, 2016, 770(1), 145-164. http://dx.doi.org/10.1007/ s10750-015-2578-5.

CAVALCANTE, H., ARAÚJO, F., NOYMA, N.P. and BECKER, V. Phosphorus fractionation in sediments of tropical semiarid reservoirs. The Science of the Total Environment, 2018, 619-620, 1022-1029. http://dx.doi.org/10.1016/j.scitotenv.2017.11.204. PMid:29734580.

CHRISTOPHORIDIS, C. and FYTIANOS, K. Conditions Affecting the Release of Phosphorus from Surface Lake Sediments. Journal of Environmental Quality, 2006, 35(4), 1181-1192. http://dx.doi. org/10.2134/jeq2005.0213. PMid:16738404.

COFFMAN, R.E. and KILDSIG, D.O. Hydrotropic Solubilization - Mechanistic Studies. Pharmaceutical Research, 1996, 13(10), 1460-1463. http://dx.doi. org/10.1023/A:1016011125302. PMid:8899835.

CORNELISSEN, G., VAN NOORT, P.C.M., PARSONS, J.R. and GOVERS, H.A.J. Temperature dependence of slow adsorption and desorption kinetics of organic compounds in sediments. Environmental Science \& Technology, 1997, 31(2), 454-460. http://dx.doi.org/10.1021/es960300+.

DE GROOT, C.J. and GOLTERMAN, H.L. On the presence of organic phosphate in some Camargue sediments: evidence for the importance of phytate. Hydrobiologia, 1993, 252(1), 117-126. http://dx.doi. org/10.1007/BF00000133.

DODDS, W.K. Eutrophication and trophic state in rivers and streams. Limnology and Oceanography, 2006, 51(1), 671-680.

DOIG, L.E., NORTH, R.L., HUDSON, J.J., HEWLETT, C., LINDENSCHMIDT, K.E. and LIBER, K. Phosphorus release from sediments in a 
river-valley reservoir in the northern Great Plains of North America. Hydrobiologia, 2017, 787(1), 323339. http://dx.doi.org/10.1007/s10750-016-2977-2.

DONG, L.M., YANG, Z.F. and LIU, X.H. Factors affecting the internal loading of phosphorus from calcareous sediments of Baiyangdian Lake in North China. Environmental Earth Sciences, 2011, 64(6), 1617-1624. http://dx.doi.org/10.1007/s12665010-0842-6.

DUTRA, R.P.S., DA SILVA, J.B., VARELA, M.L., DO NASCIMENTO, R.M., GOMES, U.U. and PASKOCIMAS, C.A. Potentiality Assessment of Clays from Rio Grande do Norte, Brazil. Part-II: Technological Properties. Cerâmica Industrial, 2008, 13(1/2), 47-50.

EMBRAPA, B.A. Brazilian Soil Classification System. Brasília: Embrapa Solos, 2018.

FIGUEIREDO, A.V. \& BECKER, V. Influence of extreme hydrological events in the quality of water reservoirs in the semi-arid tropical region. Revista Brasileira de Recursos Hidricos. 2018, 23:1-8.

FORMIGA, F.L., ANDRADE, J.C.S., ARAÚJO, P.A.S., DE MACEDO, D.A., MARTINELLI, A.E., DO NASCIMENTO, R.M. and PASKOCIMAS, C.A. Ceramic Industries of the Seridó Region (RN): Socio-economic overview and technological characterization of raw materials. Cerâmica Industrial, 2013, 18(4), 30-36. http://dx.doi.org/10.4322/ cerind.2014.053.

GÄCHTER, R. and MEYER, J.S. The role of microorganisms in mobilization and fixation of phosphorus in sediments. Hydrobiologia, 1993, 253(1-3), 103-121. http://dx.doi.org/10.1007/ BF00050731.

GÄCHTER, R., MEYER, J.S., MARES, A., MEYER, S. and GDCHTER, R. of bacteria to release and fixation of Contribution in lake sediments phosphorus Mares. Limnology and Oceanography, 1988, 33(6), 1542-1558.

GOLTERMAN, H.L. Phosphate release from anoxic sediments or "What did Mortimer really write?". Hydrobiologia, 2001, 450(1/3), 99-106. http:// dx.doi.org/10.1023/A:1017559903404.

GONSIORCZYK, T., CASPER, P. and KOSCHEL, R. Phosphorus binding forms in the sediment of an oligotrofic and eutrophic hard water lake of the baltic lake district (Germany). Water Science and Technology, 1998, 37(3), 51-58. http://dx.doi.org/10.2166/ wst. 1998.0173 .

HE, J., SU, D., LV, S., DIAO, Z., XIE, J. and LUO, Y. Effects of sediment chemical properties on phosphorus release rates in the sediment-water interface of the steppe wetlands. International Journal of Environmental Research and Public Health, 2017, 14(11), 15. http://dx.doi.org/10.3390/ ijerph14111430. PMid:29165378.
HUPFER, M. and LEWANDOWSKI, J. Oxygen controls the phosphorus release from lake sediments - A long-lasting paradigm in limnology. International Review of Hydrobiology, 2008, 93(4-5), 415-432. http://dx.doi.org/10.1002/iroh.200711054.

HUSZAR, V.L.M., SILVA, L.H.S., MARINHO, M., DOMINGOS, P. andANNA, C.L.S. Cyanoprokaryote assemblages in eight productive tropical Brazilian waters. Hydrobiologia, 2000, 424(1), 67-77. http:// dx.doi.org/10.1023/A:1003996710416.

ILLÉS, E. and TOMBÁCZ, E. The effect of humic acid adsorption on $\mathrm{pH}$-dependent surface charging and aggregation of magnetite nanoparticles. Journal of Colloid and Interface Science, 2006, 295(1), 115 123. http://dx.doi.org/10.1016/j.jcis.2005.08.003. PMid:16139290.

INTERGOVERNMENTAL PANEL ON CLIMATE CHANGE - IPCC. Climate Change 2014 Synthesis Report Summary Chapter for Policymakers. Geneva: IPCC, 2014.

JENSEN, H.S. and ANDERSEN, F.O. Importance of temperature, nitrate, and $\mathrm{pH}$ for phosphate release from aerobic sediments of four shallow, eutrophic lakes. Limnology and Oceanography, 1992, 37(3), 577 589. http://dx.doi.org/10.4319/lo.1992.37.3.0577.

JENSEN, H.S., REITZEL, K. and EGEMOSE, S. Evaluation of aluminum treatment efficiency on water quality and internal phosphorus cycling in six Danish lakes. Hydrobiologia, 2015, 751(1), 189-199. http://dx.doi.org/10.1007/s10750-015-2186-4.

JEPPESEN, E., SØNDERGAARD, M., JENSEN, J.P., HAVENS, K.E., ANNEVILLE, O., CARVALHO, L., COVENEY, M.F., DENEKE, R., DOKULIL, M.T., FOY, B., GERDEAUX, D., HAMPTON, S.E., HILT, S., KANGUR, K., KÖHLER, J., LAMMENS, E.H.H.R., LAURIDSEN, T.L., MANCA, M., MIRACLE, M.R., MOSS, B., NÓGES, P., PERSSON, G., PHILLIPS, G., PORTIELJE, R., ROMO, S., SCHELSKE, C.L., STRAILE, D., TATRAI, I., WILLÉN, E. and WINDER, M. Lake responses to reduced nutrient loading - An analysis of contemporary long-term data from 35 case studies. Freshwater Biology, 2005, 50: 1747-1771.

JESPERSEN, A.M. and CHRISTOFFERSEN, K. Measurements of chlorophyll-a from phytoplankton using ethanol as extraction solvent. Archiv für Hydrobiologie, 1988, 109, 445-454.

JIANG, X., JIN, X., YAO, Y., LI, L. and WU, F. Effects of biological activity, light, temperature and oxygen on phosphorus release processes at the sediment and water interface of Taihu Lake, China. Water Research, 2008, 42(8-9), 2251-2259. http://dx.doi.org/10.1016/j.watres.2007.12.003. PMid:18191171.

JIN, X., WANG, S., PANG, Y. and WU, F.C. Phosphorus fractions and the effect of $\mathrm{pH}$ on the phosphorus 
release of the sediments from different trophic areas in Taihu Lake, China. Environmental Pollution, 2006, 139(2), 288-295. http://dx.doi.org/10.1016/j. envpol.2005.05.010. PMid:16061319.

KAISERLI, A., VOUTSA, D. and SAMARA, C. Phosphorus fractionation in lake sediments - Lakes Volvi and Koronia, N. Greece. Chemosphere, 2002, 46(8), 1147-1155. http://dx.doi.org/10.1016/ S0045-6535(01)00242-9. PMid:11951980.

KIM, L., CHOI, E. and STENSTROM, M.K. Sediment characteristics, phosphorus types and phosphorus release rates between river and lake sediments. Chemosphere, 2003, 50(1), 53-61. http:// dx.doi.org/10.1016/S0045-6535(02)00310-7. PMid:12656229.

KOZERSKI, H.-P. and KLEEBERG, A. The Sediments and Benthic-Pelagic Exchange in the Shallow Lake Muggelsee (Berlin, Germany). International Review of Hydrobiology, 1998, 83(1), 77-112. http://dx.doi. org/10.1002/iroh.19980830109.

LEITE, J.N.C and BECKER, V. 2019. Impacts of drying and reflooding on water quality of a tropical semiarid reservoir during an extended drought event. Acta Limnologica Brasiliensia, 2019, 31, e15.

LI, H., LIU, L., LI, M. and ZHANG, X. Effects of pH, temperature, dissolved oxygen, and flow rate on phosphorus release processes at the sediment and water interface in storm sewer. Journal of Analytical Methods in Chemistry, 2013, 2013, 7. http://dx.doi. org/10.1155/2013/104316. PMid:24349823.

LÜRLING, M. \& F. VAN OOSTERHOUT. Controlling eutrophication by combined bloom precipitation and sediment phosphorus inactivation. Water Res, 2013, 47(17), 6527-6537.

MACKAY, E.B., MABERLY, S.C., PAN, G., REITZEL, K., BRUERE, A., CORKER, N., DOUGLAS, G., EGEMOSE, S., HAMILTON, D., HATTONELLIS, T., HUSER, B., LI, W., MEIS, S., MOSS, B., LÜRLING, M., PHILLIPS, G., YASSERI, S. and SPEARS, B.M. Geoengineering in lakes: Welcome attraction or fatal distraction? Inland Waters, 2014, 4(4), 349-356.

MARENGO, J.A., ALVES, L.M., ALVALA, R.C.S., CUNHA, A.P., BRITO, S. and MORAES, O.L.L. Climatic characteristics of the 2010-2016 drought in the semiarid Northeast Brazil region. Anais da Academia Brasileira de Ciências, 2018, 90(2, Suppl. 1), 1973-1985. http://dx.doi.org/10.1590/00013765201720170206 . PMid:28813107.

MARINHO, M.M., NOYMA, N.P., MAGALHÁES, L., MERCEDES, J. S., HUSZAR, V. and LÜRLING, M. External and internal phosphorus loads to a coastal urban lagoon, Jacarepaguá lagoon, Rio de Janeiro, Brazil. In: A.D. STEINMAN and B.M. SPEARS. Internal phosphorus loading in lakes. Plantation, FL: J. Ross Publishing, 2020, pp. 389-406.
MEDEIROS, L.C., MATTOS, A., LÜRLING, M. and BECKER, V. Is the future blue-green or brown? The effects of extreme events on phytoplankton dynamics in a semi-arid man-made lake. Aquatic Ecology, 2015, 49(3), 293-307. http://dx.doi.org/10.1007/s10452015-9524-5.

MENDONÇA-JÚNIOR, J.R., AMADO, A.M., VIDAL, L. O., MATTOS, A. and V. BECKER, 2018. Extreme droughts drive tropical semi-arid eutrophic reservoirs towards $\mathrm{CO} 2$ sub-saturation. Acta Limnologica Brasiliensia, 30 (101):1-11.

MISHRA, A.K. and SINGH, V.P. A review of drought concepts. Journal of Hydrology (Amsterdam), 2010, 391(1-2), 202-216. http://dx.doi.org/10.1016/j. jhydrol.2010.07.012.

MORTIMER, C.H. The Exchange of Dissolved Substances between Mud and Water in Lakes. Journal of Ecology, 1941, 30(1), 147-201. http://dx.doi. org/10.2307/2256691.

MOSLEY, L.M. Drought impacts on the water quality of freshwater systems; review and integration. EarthScience Reviews, 2015, 140, 203-214. http://dx.doi. org/10.1016/j.earscirev.2014.11.010.

MOSS, B. Allied attack: climate change and eutrophication. Inland Waters, 2014, 1(2), 101-105. http://dx.doi.org/10.5268/IW-1.2.359.

MOURA, D.S., LIMA NETO, I.E., CLEMENTE, A., OLIVEIRA, S., PESTANA, C.J., APARECIDA DE MELO, M. and CAPELO-NETO, J. Modeling phosphorus exchange between bottom sediment and water in tropical semiarid reservoirs. Chemosphere, 2020, 246, 246. http://dx.doi.org/10.1016/j. chemosphere.2019.125686. PMid:31918079.

MURPHY, J. and RILEY, J.P. A modified single solution method for the determination of phosphate in natural waters. Analytica Chimica Acta, 1962, 27, 31-36. http://dx.doi.org/10.1016/S0003-2670(00)88444-5.

NOBRE, R.L.G., CALIMAN, A., CABRAL, C.R., ARAÚJO, F.C., GUÉRIN, J., DANTAS, F.C.C., QUESADO, L.B., VENTICINQUE, E.M., GUARIENTO, R.D., AMADO, A.M., KELLY, P., VANNI, M.J. and CARNEIRO, L.S. 2020. Precipitation, landscape properties and land use interactively affect water quality of tropical freshwaters. Science of the Total Environment, 716: 137044.

NOVAIS, R.F., ALVAREZ, V.H., BARROS, N.F., FONTES, R.L.F., CANTARUTTI, R.B. and NEVES, J.C. Fertilidade do Solo. Viçosa, MG: Sociedade Brasileira de Ciência do Solo, 2007.

NURNBERG, G.K. Assessing internal phosphorus load - Problems to be solved. Lake and Reservoir Management, 2009, 25(4), 419-432. http://dx.doi. org/10.1080/00357520903458848.

RAMOS, S.O., DANTAS G.C.B., LIRA H.L., PIMENTEL, P.M. and MARCIANO, J.E.A. 
Characterization of clays of deposits new located in Parelhas/RN, Brasil, aiming for application in the ceramic industry. Revista Matéria, 2019, 24(2):1-9.

REITZEL, K., HANSEN, J., ANDERSEN, F.Ø., HANSEN, K.S. and JENSEN, H.S. Lake Restoration by Dosing Aluminum Relative to Mobile Phosphorus in the Sediment. Environmental Science \& Technology, 2005, 39(11), 4134-4140. http:// dx.doi.org/10.1021/es0485964. PMid:15984792.

REITZEL, K., HANSEN, J., JENSEN, H.S., ANDERSEN, F.Ø. and HANSEN, K.S. Testing aluminum addition as a tool for lake restoration in shallow, eutrophic Lake Sønderby, Denmark. Hydrobiologia, 2003, 506-509(13), 781-787. http://dx.doi.org/10.1023/ B:HYDR.0000008624.54844.2d.

ROCHA JUNIOR, C.A.N., DA COSTA, M.R.A., MENEZES, R.F., ATTAYDE, J.L. and BECKER, $\mathrm{V}$. Water volume reduction increases eutrophication risk in tropical semi-arid reservoirs. Acta Limnologica Brasiliensia, 2018, 30(0). http://dx.doi.org/10.1590/ s2179-975x2117.

ROLAND, F., HUSZAR, V.L., FARJALLA, V., ENRICH-PRAST, A., AMADO, A.M. and OMETTO, J.P. Climate change in Brazil: perspective on the biogeochemistry of inland waters. Brazilian Journal of Biology = Revista Brasileira de Biologia, 2012, 72(3, Suppl.), 709-722. http://dx.doi.org/10.1590/ S1519-69842012000400009. PMid:23011300.

RYDIN, E. Potentially mobile phosphorus in lake Erken sediment. Water Research, 2000, 34(7), 2037-2042. http://dx.doi.org/10.1016/S0043-1354(99)00375-9.

SCHINDLER, D.W. The dilemma of controlling cultural eutrophication of lakes. Proceedings of the Royal Society B: Biological Sciences, 2012, 279(1746), 4322-4333. http://dx.doi.org/10.1098/ rspb.2012.1032.

SILVA, I.A., COSTA, J.M.R., MENEZES, R.R., FERREIRA, H.S., NEVES, G. A. and FERREIRA, H.C. Studies of new occurrences of bentonite clays in the State of Paraíba of use in water based drilling fuids. Revista Escola de Minas: Mineração, 2013, 66(4):485-491.

SILVA, P.C.G., MOURA, M.S.B., KIILL, L.H.P., BRITO, L.T.L., PEREIRA, L.A., SA, I.B., CORREIA, R.C., TEIXEIRA, A.H.C., CUNHA, T.J.F., GUIMARÃES FILHO, C. Caracterização do Semiárido brasileiro: fatores naturais e humanos. In: I.B. SA and P.C.G. SILVA, eds. Semiárido brasileiro: pesquisa, desenvolvimento e inovação. Petrolina, PE: Embrapa Semiárido, 2010, pp. 18-48.

SMITH, V.H. and SCHINDLER, D.W. Eutrophication science: Where do we go from here? Trends in Ecology \& Evolution, 2009, 24(4), 201-207. http://dx.doi. org/10.1016/j.tree.2008.11.009. PMid:19246117.
SØNDERGAARD, M. Nutrient dynamics in lakes - with emphasis on phosphorus, sediment and lake restoration [Doctor's dissertation]. Denmark: University of Aarhus, 2007.

SØNDERGAARD, M., BJERRING, R. and JEPPESEN, E. Persistent internal phosphorus loading during summer in shallow eutrophic lakes. Hydrobiologia, 2013, 710(1), 95-107. http://dx.doi. org/10.1007/s10750-012-1091-3.

SØNDERGAARD, M., JENSEN, J.P. and JEPPESEN, E. Retention and Internal Loading of Phosphorus in Shallow, Eutrophic Lakes. TheScientific WorldJournal, 2001, 1, 427-442. http://dx.doi.org/10.1100/ tsw.2001.72. PMid:12806078.

SØNDERGAARD, M., JENSEN, J.P. and JEPPESEN, E. Role of sediment and internal loading of phosphorus in shallow lakes. Hydrobiologia, 2003, 506-509(1-3), 135-145. http://dx.doi.org/10.1023/ B:HYDR.0000008611.12704.dd.

THORNTON, J.A. and RAST, W. A test of hypotheses relating to the comparative limnology and assessment of eutrophication in semi-arid man-made lakes. In: M. STRASKRABA, J.G. TUNDISI and A. DUNCAN, eds. Comparative reservoir limnology and water quality management. Dordrecht, The Netherlands: Kluwer Academic Publishers, 1993, pp. 1-24.

VALDERRAMA, J.C. The simultaneous analysis of total nitrogen and total phosphorus in natural waters. Marine Chemistry, 1981, 10(2), 109-122. http:// dx.doi.org/10.1016/0304-4203(81)90027-X.

VICENTE, I., HUANG, P., ANDERSEN, F.Ø. and JENSEN, H.S. Phosphate adsorption by fresh and aged aluminum hydroxide. Consequences for lake restoration. Environmental Science \& Technology, 2008, 42(17), 6650-6655. http://dx.doi. org/10.1021/es800503s. PMid:18800544.

VILAR, C.C., COSTA A.C.S., HOEPERS A. and JUNIOR, I.G. S. Maximum phosphorus adsorption capacity as related to iron and aluminum forms in subtropical soils. Revista Brasileira de Ciencia do Solo, 2010, 34(1), 1059-1068.

WANG, J., CHEN, J., DING, S., LUO, J. and XU, Y. Effects of temperature on phosphorus release in sediments of Hongfeng Lake, southwest China: An experimental study using diffusive gradients in thin-films (DGT) technique. Environmental Earth Sciences, 2015, 74(7), 5885-5894. http://dx.doi. org/10.1007/s12665-015-4612-3.

WETZEL, R.G. Limnology: Lake and River Ecosystems. San Diego: Acadmic Press, 2001.

YANG, C., YANG, P., GENG, J., YIN, H. and CHEN, K. Sediment internal nutrient loading in the most polluted area of a shallow eutrophic lake (Lake Chaohu, China) and its contribution to lake eutrophication. Environmental Pollution, 
2020a, 262, 114292. http://dx.doi.org/10.1016/j. envpol.2020.114292. PMid:32179221.

YANG, Y., ZHANG, J., LIU, L., WANG, G., CHEN, M., ZHANG, Y. and TANG, X. Experimental study on phosphorus release from sediment with freshwater snail (Bellamya aeruginosa) bioturbation in eutrophic lakes. Journal of Soils and Sediments, 2020b, 20(5), 2526-2536. http://dx.doi.org/10.1007/ s11368-020-02614-2.

ZHU, B., WANG, Z. and ZHANG, X. Phosphorus fractions and release potential of ditch sediments from different land uses in a small catchment of the upper Yangtze River. Journal of Soils and Sediments, 2012, 12(2), 278-290. http://dx.doi.org/10.1007/ s11368-011-0449-x.

Received: 20 October 2020

Accepted: 09 March 2021

Associate Editor: André Megali Amado. 